\title{
ЗМІНИ АКТИВНОСТІ ПРООКСИДАНТНО-АНТИОКСИДАНТНОЇ СИСТЕМИ В РАННІЙ ПЕРІОД РОЗВИТКУ ПОЛІТРАВМИ ТА КОРЕКЦІЯ ПЕНТОКСИФІЛІНОМ
}

Вступ. Травма є однією з причин виникнення оксидативного стресу. Мембраностабілізувальні, протекторні, антикальцієві, антиангінальні та антиагрегантні властивості ксантинів, зокрема пентоксифріліну, поряд з іншими притаманними їм фрармакодинамічними ефректами, здатні попереджувати фрормування незворотних патологічних змін у різних органах і тканинах.

Мета дослідження - визначити особливості змін активності прооксидантно-антиоксидантної системи в ранній період розвитку політравми та ефективність застосування при цьому пентоксиоріліну.

Методи дослідження. Досліди проведено на білих безпородних статевозрілих щурах-самцях. У плазмі крові й тканині печінки визначали вміст малонового діальдегіду та гідропероксидів ліпідів, у печінці та плазмі крові - ступінь активності каталази і вміст церулоплазміну. 3 метою корекції застосовували пентоксифрілін. Препарат вводили внутрішньочеревно один раз на добу у вигляді 2 \% водного розчину в дозі 25 мг/ке упродовж 7-ми днів.

Результати й обговорення. Застосування пентоксифріліну в експериментальних тварин з моделлю політравми призвело до зниження концентрації гідропероксидів ліпідів та малонового діальдегіду в плазмі крові вже з 1-ї доби дослідження. Введення препарату спричинило достовірне зменшення вмісту гідропероксидів ліпідів та малонового діальдегіду в печінці тварин протягом усього періоду спостереження. Статистично значуще зниження активності каталази у плазмі крові відзначали на 1-шу і 3-тю доби експерименту. Підвищення ії у тканині печінки спостерігали з 3-ї доби дослідження. Статистично значущого впливу на рівень церулоплазміну в печінці та плазмі крові після введення пентоксифіліну не виявлено.

Висновок. За умов експериментальної політравми і введення щурам пентоксифріліну у вигляді 2 \% водного розчину в дозі 25 мг/кг протягом 7-ми днів спостерігали зниження активності прооксидантної системи та достовірне підвищення активності каталази в паренхімі печінки.

КЛЮЧОВІ СЛОВА: політравма; прооксидантно-антиоксидантна система; оксидативний стрес; пентоксифілін.

ВСТУП. Травмає однією з причин виникнення оксидативного стресу [1]. При травматичному ушкодженні його викликають переважно три основних причини: розвиток некротичного і запального процесів, реакція фрагоцитуючих клітин та гіпоксія. Кожен із цих шляхів зумовлює активацію комплементу, поліморфноядерних клітин і макрофрагів, підвищення рівня активних фрорм кисню [2]. Гіпоксія і шок стимулюють утворення ендотеліну-1 та продуктів метаболізму монооксиду азоту, призводячи до вазоконстрикції, розвитку ішемії, подальшого вивільнення цитокінів, у тому числі фрактора некрозу пухлини-альфра. Дані зміни викликають загибель клітин шляхом некрозу/апоптозу або диссрункції ендотелію судин та органів [3, 4].

(с) О. О. Кулянда, 2019
Таким чином, генез травматичної хвороби ґрунтується на дискоординації систем макро- і мікроциркуляції 3 подальшим зниженням тканинної перфузії, порушенням клітинного метаболізму та біохімічних констант організму, розвитком первинної і вторинної (токсичної) поліорганної недостатності, синдрому взаємного обтяження. При цьому заслуговує на увагу використання з лікувальною метою засобів, що впливають на зазначені ланки патогенезу політравми як клітинного, так і судинного напрямків $[5,6]$.

Відомо, що одним із найбільш активних ксантинів є пентоксифрілін. Ряд дослідників фріксує увагу на його багатовекторній дії, що проявляється при лікуванні різних захворювань і яку неможливо пояснити лише ангіореологічною 
дією препарату [7]. У ряді досліджень ідеться про здатність препаратів із похідних ксантину нормалізувати стан окисного гомеостазу організму [8]. Пентоксифрілін попереджує виснаження системи антиоксидантного захисту при гіпоксії, зберігаючи активність її ключових ензимів, підвищуючи внутрішньоклітинний рівень цАМФ шляхом пригнічення фоосродіестерази. Мембраностабілізувальні, протекторні, антикальцієві, антиангінальні та антиагрегантні властивості ксантинів, зокрема пентоксифріліну, поряд з іншими властивими їм фрармакодинамічними ефректами, здатні попереджувати фрормування незворотних патологічних змін у різних органах і тканинах [9-11].

Мета дослідження - визначити особливості змін активності прооксидантно-антиоксидантної системи в ранній період розвитку політравми та есрективність застосування при цьому пентоксифріліну.

МЕТОДИ ДОСЛІДЖЕННЯ. 3 метою реалізації поставленої мети досліди проведено на 70 білих статевозрілих нелінійних щурах-самцях, яких утримували на стандартному раціоні віварію. Експериментальних тварин з вихідною масою 180-200 г рандомізували методом випадкової вибірки.

Досліди проводили відповідно до положень Загальних етичних принципів експериментів на тваринах, ухвалених на Першому національному конгресі з біоетики (Київ, 2001), Європейської конвенції про захист хребетних тварин, що використовуються для дослідних та інших наукових цілей (Страсбург, 1986), і вимог комісії з біоетики Тернопільського державного медичного університету імені І. Я. Горбачевського (протокол № 23 від 05.05.2014 р.).

У 1-й групі було відтворено модель політравми за Кенноном у модифікації [12]. Під тіопентал-натрієвим знеболюванням (40 мг на 1 кг маси) в асептичних умовах викликали у тварин кровотечу зі стегнової вени (близько 20 \% об'єму циркулюючої крові, 1 мл якої вводили у паранефрральну клітковину для відтворення ендоген- ної інтоксикації). Далі щипцями Люера ламали ліву стегнову кістку.

Декапітацію тварин здійснювали під тіопентал-натрієвим знеболюванням через 24 год після останнього введення засобу корекції. Для дослідження використовували плазму крові й гомогенат печінки.

Усіх піддослідних тварин було поділено на такі групи, як: контрольна (10 щурів); 1-ша група - 30 тварин з політравмою без корекції (дослідження проводили на 1-шу, 3-тю і 7-му доби експерименту, що відповідає ранньому періоду розвитку травматичної хвороби); 2-га група - 30 тварин з політравмою, яким проводили корекцію пентоксисріліном (препарат вводили внутрішньочеревно один раз на добу у вигляді $2 \%$ водного розчину в дозі 25 мг/кг упродовж 7-ми днів) [13].

Активність процесів пероксидного окиснення ліпідів досліджували у плазмі крові та тканині печінки (визначали вміст малонового діальдегіду-МДА і гідропероксидів ліпідів - ГПЛ) $[14,15]$.

Стан антиоксидантної системи вивчали за активністю в печінці та плазмі крові каталази (КАТ) і вмістом церулоплазміну (ЦП) [16].

РЕЗУЛЬТАТИ Й ОБГОВОРЕННЯ. ЯК СвіДчаТЬ дані таблиці 1, застосування пентоксифіліну призвело до достовірного пригнічення у травмованих тварин процесів ліпопероксидації. Так, уже через 24 год вміст проміжних продуктів пероксидного окиснення ліпідів - гідропероксидів ліпідів у плазмі крові тварин 2-ї групи виявився в 1,4 раза меншим $\left(p_{1}<0,01\right)$ порівняно зі щурами 1-ї групи. На 3-тю добу вміст ГПЛ продовжував достовірно знижуватися і був у 1,4 раза меншим $\left(\mathrm{p}_{1}<0,01\right)$ за відповідний показник у тварин 1-ї групи. Повторне внутрішньочеревне введення пентоксисріліну призвело до подальшого зниження цього показника, і на 7-му добу експерименту він став у 1,5 раза меншим $\left(p_{1}<0,001\right)$, ніж у щурів, яким не вводили пентоксифріліну.

У такому ж напрямку змінювалася в крові також концентрація малонового діальдегіду. В усі терміни спостереження вона була достовірно

Таблиця 1 - Динаміка вмісту продуктів пероксидного окиснення ліпідів у плазмі крові тварин

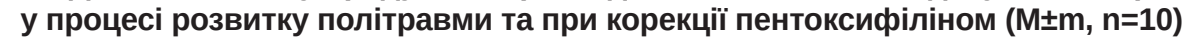

\begin{tabular}{|l|c|c|c|c|c|c|c|}
\hline \multirow{2}{*}{ Показник } & \multicolumn{5}{|c|}{ Група тварин } \\
\cline { 2 - 8 } & \multirow{2}{*}{ контрольна } & \multicolumn{3}{|c|}{ 1-ша } & \multicolumn{3}{c|}{} \\
\cline { 3 - 8 } & & 1-ша доба & 3-тя доба & 7-ма доба & 1-ша доба & 3-тя доба & 7-ма доба \\
\hline ГПЛ, & $2,23 \pm 0,28$ & $3,14 \pm 0,19$ & $3,31 \pm 0,24$ & $3,01 \pm 0,17$ & $2,20 \pm 0,24$ & $2,34 \pm 0,17$ & $2,07 \pm 0,13$ \\
$10^{3}$ ум. од./л & & $\mathrm{p}<0,02$ & $\mathrm{p}<0,01$ & $\mathrm{p}<0,05$ & $\mathrm{p}_{1}<0,01$ & $\mathrm{p}_{1}<0,01$ & $\mathrm{p}_{1}<0,001$ \\
\hline МДА, & $1,90 \pm 0,16$ & $2,71 \pm 0,13$ & $3,15 \pm 0,17$ & $2,74 \pm 0,23$ & $1,74 \pm 0,13$ & $2,01 \pm 0,17$ & $1,86 \pm 0,18$ \\
мкмоль/л & & $\mathrm{p}<0,001$ & $\mathrm{p}<0,001$ & $\mathrm{p}<0,01$ & $\mathrm{p}_{1}<0,001$ & $\mathrm{p}_{1}<0,001$ & $\mathrm{p}_{1}<0,01$ \\
\hline
\end{tabular}

Примітка. Тут і в таблицях 2, 3: p - достовірність відмінності показників відносно контрольної групи; p $_{1}$ достовірність відмінності показників відносно 1-ї групи. 
нижчою від відповідного показника у тварин без корекції пентоксифріліном. Зокрема, на 1-шу добу концентрація МДА виявилася меншою на 35,8 \% $\left(p_{1}<0,001\right)$, на 3-тю - на 36,2 \% $\left(p_{1}<0,001\right)$ та на 7-му - на 32,1 \% $\left(p_{1}<0,01\right)$ порівняно зі щурами 1-ї групи.

Лікувальний вплив пентоксифріліну на процеси ліпопероксидації проявився і в печінці травмованих тварин. Як свідчать дані таблиці 2, внутрішньочеревне введення препарату призвело до достовірного зниження вмісту ГПЛ: в 1,4 раза $\left(\mathrm{p}_{1}<0,05\right)$ - через 24 год після моделювання політравми, в 1,5 раза ( $\left.\mathrm{p}_{1}<0,001\right)$ - на 3-тю добу та в 1,5 раза $\left(p_{1}<0,01\right)$ - на 7-му добу експерименту.

Також мало місце зниження концентрації малонового діальдегіду в печінці тварин, яким проводили корекцію пентоксифіліном. Так, на 1-шу і 3-тю доби експерименту вона була достовірно нижчою, відповідно, в 1,5 раза $\left(\mathrm{p}_{1}<0,001\right)$ та 1,6 раза ( $\left.p_{1}<0,001\right)$, а на 7-му добу - в 1,5 раза $\left(p_{1}<0,001\right)$ порівняно з травмованими тваринами 1-ї групи, яким не вводили пентоксиоріліну.

Нижче наведено результати вивчення впливу пентоксифіліну на активність каталази в плазмі крові й печінці щурів та активність антиоксиданта нефрерментативної природи церулоплазміну в плазмі крові на 1-шу, 3-тю і 7-му доби з моменту моделювання політравми.

Уже після одноразового внутрішньочеревного введення пентоксифріліну щурам із політравмою спостерігали статистично значуще зменшення активності одного з основних клітинних антиоксидантних ензимів, що блокують ланцюг ліпопероксидації на початкових стадіях, - каталази (табл. 3). У цьому випадку активність ензиму в плазмі крові даних тварин достовірно знизилася на $27,3 \%\left(p_{1}<0,001\right)$ порівняно зі щурами 1-ї групи. На 3-тю добу спостереження вона достовірно зменшилася на 19,0 \% ( $\left.p_{1}<0,02\right)$. Зниження активності досліджуваного ензиму в цій групі тварин спостерігали також на 7-му добу експерименту, однак зміни були недостовірними. Зменшення активності даного ензиму можна пояснити гальмуванням процесів пероксидного окиснення ліпідів після введення пентоксифріліну, що, у свою чергу, запобігає ранньому виснаженню антиоксидантної системи.

Підвищення активності каталази за умов експерименту спостерігали у тканині печінки. Як показали результати досліджень, при корекції пентоксифріліном вона статистично достовірно зростала, починаючи з 3-ї доби експерименту. Зокрема, на 3-тю добу активність КАТ перевищувала показник тварин 1-ї групи на 22,0% і становила $(3,38 \pm 0,16)$ мкат/кг $\left(p_{1}<0,02\right)$, а на 7-му - на 25,5 \%, складаючи $(3,40 \pm 0,12)$ мкат/кг $\left(p_{1}<0,02\right)$.

Статистично значущого впливу на активність ЦП, окрім її незначного зниження на 1-шу добу експерименту, після введення пентоксифіліну не виявлено.

Таблиця 2 - Динаміка вмісту продуктів пероксидного окиснення ліпідів у печінці тварин у процесі

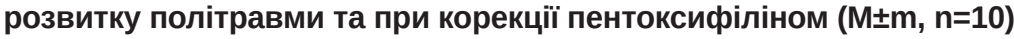

\begin{tabular}{|c|c|c|c|c|c|c|c|}
\hline \multirow{3}{*}{ Показник } & \multicolumn{7}{|c|}{ Група тварин } \\
\hline & \multirow[b]{2}{*}{ контрольна } & \multicolumn{3}{|c|}{ 1-ша } & \multicolumn{3}{|c|}{ 2-га } \\
\hline & & 1-ша доба & 3-тя доба & 7-ма доба & 1-ша доба & 3-тя доба & 7-ма доба \\
\hline ГПЛ, $10^{3}$ ум. од./кг & $1,58 \pm 0,27$ & $\begin{array}{c}2,37 \pm 0,22 \\
p<0,05\end{array}$ & $\begin{array}{c}2,95 \pm 0,13 \\
p<0,001\end{array}$ & $\begin{array}{c}2,74 \pm 0,21 \\
p<0,01\end{array}$ & $\begin{array}{c}1,68 \pm 0,16 \\
p_{1}<0,05\end{array}$ & $\begin{array}{c}1,92 \pm 0,15 \\
p_{1}<0,001\end{array}$ & $\begin{array}{c}1,88 \pm 0,17 \\
p_{1}<0,01\end{array}$ \\
\hline МДА, мкмоль/кг & $3,84 \pm 0,30$ & $\begin{array}{c}8,34 \pm 0,35 \\
p<0,001\end{array}$ & $\begin{array}{c}9,14 \pm 0,40 \\
p<0,001\end{array}$ & $\begin{array}{c}8,06 \pm 0,47 \\
p<0,001\end{array}$ & $\begin{array}{c}5,70 \pm 0,53 \\
p_{1}<0,001\end{array}$ & $\begin{array}{c}5,07 \pm 0,47 \\
p_{1}<0,001\end{array}$ & $\begin{array}{c}4,80 \pm 0,28 \\
p_{1}<0,001\end{array}$ \\
\hline
\end{tabular}

Таблиця 3 - Активність антиоксидантних ензимів у плазмі крові щурів у процесі розвитку

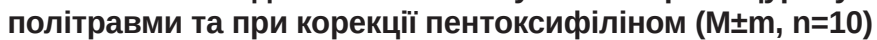

\begin{tabular}{|c|c|c|c|c|c|c|c|}
\hline \multirow{3}{*}{ Показник } & \multicolumn{7}{|c|}{ Група тварин } \\
\hline & \multirow{2}{*}{ контрольна } & \multicolumn{3}{|c|}{ 1-ша } & \multicolumn{3}{|c|}{ 2-га } \\
\hline & & 1-ша доба & 3-тя доба & 7-ма доба & 1-ша доба & 3-тя доба & 7-ма доба \\
\hline $\begin{array}{l}\text { КАТ, } \\
\text { мкат/л }\end{array}$ & $0,18 \pm 0,01$ & $\begin{array}{c}0,22 \pm 0,01 \\
p<0,02\end{array}$ & $\begin{array}{c}0,21 \pm 0,01 \\
p<0,05\end{array}$ & $\begin{array}{c}0,19 \pm 0,01 \\
p>0,05\end{array}$ & $\begin{array}{c}0,16 \pm 0,01 \\
p_{1}<0,001\end{array}$ & $\begin{array}{c}0,17 \pm 0,01 \\
p_{1}<0,02\end{array}$ & $\begin{array}{c}0,18 \pm 0,01 \\
p_{1}>0,05\end{array}$ \\
\hline $\begin{array}{l}\text { ЦП, } \\
\text { г/л }\end{array}$ & $0,23 \pm 0,01$ & $\begin{array}{c}0,30 \pm 0,02 \\
p<0,01\end{array}$ & $\begin{array}{c}0,28 \pm 0,01 \\
p<0,002\end{array}$ & $\begin{array}{c}0,26 \pm 0,01 \\
p<0,05\end{array}$ & $\begin{array}{c}0,25 \pm 0,01 \\
p_{1}<0,05\end{array}$ & $\begin{array}{c}0,26 \pm 0,01 \\
p_{1}>0,05\end{array}$ & $\begin{array}{c}0,24 \pm 0,01 \\
p_{1}>0,05\end{array}$ \\
\hline
\end{tabular}

ВИСНОВОК. За умов експериментальної політравми і введення щурам пентоксисіліну у вигляді 2 \% водного розчину в дозі 25 мг/кг про- тягом 7-ми днів спостерігали зниження активності прооксидантної системи та достовірне підвищення активності каталази в паренхімі печінки. 


\section{СПИСОК ЛІТЕРАТУРИ}

1. Influence of antioxidant therapy on the clinical status of multiple trauma patients. A retrospective single center study // Rom. J. Anaesth. Intensive Care. - 2015. 22 (2). - P. 89-96.

2. Oxidative stress in severe pulmonary trauma in critical ill patients. Antioxidant therapy in patients with multiple trauma-A review / O. H. Bedreag, A. F. Rogobete, M. Sarandan [et al.] // Anaesthesiol. Intensive Ther. 2015. - 47 (4). - P. 351-359. Access mode : https://doi. org/10.5603/AIT.a2015.0030

3. Sies H. Redox Biology Oxidative stress: a concept in redox biology and medicine / H. Sies // Redox Biol. 2015. - 4. - P. 180-183.

4. Antioxidant responses and cellular adjustments to oxidative stress / C. Espinosa-Diez, V. Miguel, D. Mennerich [et al.] // Redox Biol. - 2015. - 6. - P. 183-197. Access mode: https://doi.org/10.1016/j.redox.2015.07.008.

5. Oxidative stress in severe pulmonary trauma in critical ill patients. Antioxidant therapy in patients with multiple trauma-A review / O. H. Bedreag, A. F. Rogobete, M. Sarandan [et al.] // Anaesthesiol. Intensive Ther. 2015. - 47 (4). - P. 351-359. Access mode : https://doi. org/10.5603/AIT.a2015.0030.

6. Kozak D. V. Lipid peroxidation, antioxidant defence, endogenous intoxication and cytolysis variations in early and late manifestations of traumatic disease I D. V. Kozak // J. Health Sci. - 2013. - 3, No. 4. - P. 108117.

7. Pentoxifylline neuroprotective effects are possibly related to its anti-inflammatory and TNF-alpha inhibitory properties, in the 6-OHDA model of Parkinson's disease / K. R. Neves, H. V. Jr. Nobre, L. K. Leal [et al.] // Parkinsons Dis. - 2015. - P. 108179

8. Shilan Mozaffari. A review on the role of oxidative stress and inflammation in necrotizing enterocolitis and benefits of the phosphodiesterase inhibitor pentoxifylline /

\section{REFERENCES}

1. (2015). Influence of antioxidant therapy on the clinical status of multiple trauma patients. A retrospective single center study. Rom. J. Anaesth. Intensive Care, 22 (2), 89-96.

2. Bedreag, O.H., Rogobete, A.F., Sarandan, M., Cradigati, A.C., Papurica, M., Dumbuleu, M.C., ... \& Sandesc, D. (2015). Oxidative stress in severe pulmonary trauma in critical ill patients. Antioxidant therapy in patients with multiple trauma-A review. Anaesthesiol. Intensive Ther., 47 (4), 351-359. Retrieved from: https://doi. org/10.5603/AIT.a2015.0030

3. Sies, H. (2015). Redox biology oxidative stress: a concept in redox biology and medicine. Redox Biol., 4, 180-183.

4. Espinosa-Diez, C., Miguel, V., Mennerich, D., Kietzmann, T., SánchezPérez, P., Cadenas, S., \& Lamas, S. (2015). Antioxidant responses and cellular adjustments to oxidative stress. Redox Biol., 6, 183-197. Retrieved from: https://doi.org/10.1016/j.redox.2015.07.008.
Shilan Mozaffari, Mohammad Abdollahi // International Journal of Pharmacology. 2013. - 9 (4). - P. 245-250.

9. Pentoxifylline improves cutaneous wound healing in streptozotocin-induced diabetic rats / S. Babaei, M. Bayat, M. Nouruzian, M. Bayat// Eur. J. Pharmacol. 2013. - 700. - P. 165-172.

10. The role of pentoxifylline on neuroprotection in neonatal rat model of hypoxic ischemic brain injury / Hülya Halis, Narin Liman, Osman Baştuğ, Tamer Güneş // Curr. Pediatr. Res. - 2017. - 21 (1). - P. 77-85.

11. Кулянда О. О. Динаміка профрілю цитокінів при застосуванні пентоксифріліну в умовах політравми / О. О. Кулянда // Клініч. хірургія. - 2013. - № 12. C. $73-75$.

12. Пат. 63997 Україна, МПК G 09 В 23/28. Спосіб моделювання політравми / Козак Д. В. ; заявник і патентовласник Терноп. держ. мед. ун-т імені І. Я. Горбачевського. - № и 201104110 ; заявл. 05.04.11 ; опубл. 25.10.11, Бюл. № 20.

13. Пат. 86467 Україна, МПК (2013.01) А61 В 17/00. Спосіб корекції балансу цитокінів при політравмі в експерименті / Корда М. М., Кулянда О. О., Кулянда І. С., Коптюх В. В. ; заявник і патентовласник Терноп. держ. мед. ун-т імені І. Я. Горбачевського. № u 201309854 ; заявл. 08.08.13 ; опубл. 25.12.13, Бюл. № 24.

14. Андреева Л. И. Модисрикация метода определения перекисей липидов в тесте с тиобарбитуровой кислотой / Л. И. Андреева, Л.А.Кожемякин, А. А. Кишкун // Лаб. дело. - 1988. - № 11. - С. 41-43.

15. Гаврилов В. Б. Спектрофотометрическое определение гидроперекисей липидов в плазме крови / В. Б. Гаврилов, М. И. Мишкорудная // Лаб. дело. 1983. - № 3. - С. 33-35.

16. Метод определения активности каталазы / М. А. Королюк, Л. И. Иванова, Н. Г. Майорова, В. Е. Токарев // Лаб. дело. - 1988. - № 1. - С. 16-19.

5. Bedreag, O.H., Rogobete, A.F., Sarandan, M. Cradigati, A.C., Papurica, M., \& Dumbuleu, M.C. (2015). Oxidative stress in severe pulmonary trauma in critical ill patients. Antioxidant therapy in patients with multiple trauma-A review. Anaesthesiol. Intensive Ther., 47 (4), 351-359. Retrieved from: https://doi.org/10.5603/AIT. a2015.0030.

6. Kozak, D.V. (2013). Lipid peroxidation, antioxidant defence, endogenous intoxication and cytolysis variations in early and late manifestations of traumatic disease. $\mathrm{J}$. Health Sci., 3, 4, 108-117.

7. Neves, K.R., Nobre, H.V.Jr., Leal, L.K., de Andrade, G.M., Brito, G.A., \& Viana, G.S. (2015). Pentoxifylline neuroprotective effects are possibly related to its antiinflammatory and TNF-alpha inhibitory properties, in the 6-OHDA model of Parkinson's disease. Parkinsons Dis., 108179.

8. Mozaffari, S., \& Abdollahi, M. (2013). A review on the role of oxidative stress and inflammation in necrotizing 
enterocolitis and benefits of the phosphodiesterase inhibitor pentoxifylline. International Journal of Pharmacology, 9 (4), 245-250.

9. Babaei, S., Bayat, M., Nouruzian, M., \& Bayat, M. (2013). Pentoxifylline improves cutaneous wound healing in streptozotocin-induced diabetic rats. Eur. J. Pharmacol., 700, 165-172.

10. Halis, H., Liman, N., Baştuğ, O., \& Güneş, T. (2017). The role of pentoxifylline on neuroprotection in neonatal rat model of hypoxic ischemic brain injury. Curr. Pediatr. Res., 21 (1), 77-85.

11. Kulianda, O.O. (2013). Dynamika profiliu tsytokiniv pry zastosuvanni pentoksyfilinu $v$ umovakh politravmy [Dynamics of the profile of cytokines in the use of pentoxifylline in the conditions of polytrauma]. Klinich. khirurhiia - Clinical Surgery, 12, 73-75 [in Ukrainian]

12. Pat. 63997 Ukraina, MPK G 09 V 23/28. Sposib modeliuvannia politravmy. Kozak D.V. ; zaiavnyk i patentovlasnyk Ternopil. derzh. med. un-t imeni I. Ya. Horbachevskoho. - № u 201104110 ; zaiavl. 05.04.11; opubl. 25.10.11, Biul. № 20. 14. [Patent 63997 Ukraine, IPC G 09 at $23 / 28$. Method of modeling polytrauma. Kozak D.V. ; Applicant and patent owner of I. Horbachevsky Ternopil State Medical University. No. u 201104110; stated. 05/04/11; published October 25, 10, Bull. No. 20]. [in Ukrainian].

13. Pat. 86467 Ukraina, MPK (2013.01)A61 B 17/00. Sposib korektsii balansu tsytokiniv pry politravmi $\vee$ eksperymenti / Korda M. M., Kulyanda O. O., Kulyanda I. S., Koptyukh V. V. ; zaiavnyk i patentovlasnyk Ternopil. derzh. med. un-t imeni I. Ya. Horbachevskoho. № u 201309854 ; zaiavl. 08.08.13 ; opubl. 25.12.13, Byul. № 24 [Patent 86467 Ukraine, IPC (2013.01) A61 B 17/00. Method of correction of balance of cytokines with polytrauma in experiment / Korda, M.M., Kulianda O.O., Kulianda, I.S., Koptiuk, V.V.; Applicant and patent owner of I. Horbachevsky Ternopil State Medical University. No. u 2013 09854; stated. 08.08.13; published 25.12.13, Bul. No. 24 [in Ukrainian].

14. Andreyeva, L.I., Kozhemyakin, L.A., \& Kishkun, A.A. (1988). Modifikatsiya metoda opredeleniya perekisey lipidov v teste s tiobarbiturovoy kislotoy [Modification of the method for determining lipid peroxides in a test with thiobarbituric acid]. Lab. delo - Laboratory Work, 11, 41-43 [in Russian].

15. Gavrilov, V.B., \& Mishkorudnaya, M.I. (1983). Spektrofotometricheskoye opredeleniye gidroperekisey lipidov v plazme krovi [Spectrophotometric determination of lipid hydroperoxides in blood plasma]. Lab. delo. Laboratory Work, 3, 33-35 [in Russian].

16. Korolyuk, M.A., Ivanova, L.I., Mayorova, N.G., \& Tokarev, V.Ye. (1988). Metod opredeleniya aktivnosti katalazy [Method for determining catalase activity]. Lab. delo - Laboratory Work, 1, 16-19 [in Russian].

ТЕРНОПОЛЬСКИЙ ГОСУДАРСТВЕННЫЙ МЕДИЦИНСКИЙ УНИВЕРСИТЕТ ИМЕНИ И. Я. ГОРБАЧЕВСКОГО

\section{ИЗМЕНЕНИЯ АКТИВНОСТИ ПРООКСИДАНТНО-АНТИОКСИДАНТНОЙ СИСТЕМЫ В РАННИЙ ПЕРИОД РАЗВИТИЯ ПОЛИТРАВМЫ И КОРРЕКЦИЯ ПЕНТОКСИФИЛЛИНОМ}

\section{Резюме}

Вступление. Травма является одной из причин возникновения оксидативного стресса. Мембраностабилизирующие, протекторные, антикальциевые, антиангинальные и антиагрегантные свойства ксантинов, в частности пентоксифиллина, наряду с другими присущими им фрармакодинамическими эфрфектами, способны предупреждать фрормирование необратимых патологических изменений в различных органах и тканях.

Цель исследования - определить особенности изменений активности прооксидантно-антиоксидантной системы в ранний период развития политравмы и эффрективность применения при этом пентоксифиллина.

Методы исследования. Опыты проведены на белых беспородных половозрелых крысах-самцах. В плазме крови и ткани печени определяли содержание малонового диальдегида и гидроперекисей липидов, в печени и плазме крови - степень активности каталазы и содержание церулоплазмина. С целью коррекции применяли пентоксифиллин. Препарат вводили внутрибрюшно один раз в сутки в виде 2 \% водного раствора в дозе 25 мг/кг в течение 7-ми дней.

Результаты и обсуждение. Применение пентоксифиллина у экспериментальных животных с моделью политравмы привело к снижению концентрации гидроперекисей липидов и малонового диальдегида в плазме крови уже с первых суток исследования. Введение препарата вызвало достоверное уменьшение содержания гидроперекисей липидов и малонового диальдегида в печени животных в течение 
всего периода наблюдения. Статистически значимое снижение активности каталазы в плазме крови отмечали на первые и третьи сутки эксперимента. Повышение ее в ткани печени наблюдали с третих суток исследования. Статистически значимого влияния на уровень церулоплазмина в печени и плазме крови после введения пентоксифиллина не обнаружено.

Вывод. В условиях экспериментальной политравмы и введения крысам пентоксифиллина в виде $2 \%$ водного раствора в дозе 25 мг/кг в течение 7-ми дней наблюдали снижение активности прооксидантной системы и достоверное повышение активности каталазы в паренхиме печени.

КЛЮЧЕВЫЕ СЛОВА: политравма; прооксидантно-антиоксидантная система; оксидативный стресс; пентоксифиллин.

O. O. Kulianda

I. HORBACHEVSKY TERNOPIL STATE MEDICAL UNIVERSITY

\section{CHANGES OF THE PROOXIDANT-ANTIOXIDANT SYSTEM ACTIVITY IN THE EARLY PERIOD OF POLYTRAUMA DEVELOPMENT AND PENTOXIFYLLINE CORRECTION}

\section{Summary}

Introduction. Trauma is one of the causes of oxidative stress. Membrane stabilizing, tread, anti-calcium, antianginal and anti-aggregant properties of xanthines, in particular pentoxifylline, along with other inherent pharmacodynamic effects, can prevent the formation of irreversible pathological changes in various organs and tissues.

The aim of the study - to determine the peculiarities of the changes of the prooxidant-antioxidant system in the early period of polytrauma development and the effectiveness of using pentoxifylline.

Research Methods. Experiments were conducted on white, non-breeding, sexually mature male rats. The content of malondialdehyde and lipid hydroperoxides was determined in the liver tissue and blood plasma. The level of catalase and ceruloplasmin activity in the liver and blood plasma were determined. For the purpose of correction, pentoxifylline was used. The drug was injected intraperitoneally once a day in the form of $2 \%$ aqueous solution at a dose of $25 \mathrm{mg} / \mathrm{kg}$ for 7 days.

Results and Discussion. The use of pentoxifylline in experimental animals with a model of polytrauma led to a decrease in the concentration of lipid hydroperoxides and malonic dialdehyde in the blood plasma already from the 1st day of the study. The introduction of pentoxifylline caused a significant decrease in the content of lipid hydroperoxides and malondialdehyde in the liver of animals during the entire observation period. A statistically significant decrease in plasma catalase activity was noted in the first and third days of the experiment. Its increase in liver tissue was observed from the 3rd day of the study. No statistically significant effect on the level of ceruloplasmin in the liver and plasma after administration of pentoxifylline was detected.

Conclusion. Under the conditions of experimental polytrauma and introduction of pentoxifylline in the form of $2 \%$ aqueous solution at a dose of $25 \mathrm{mg} / \mathrm{kg}$ within 7 days, the decrease in the activity of the prooxidant system and a significant increase in the activity of catalase in liver parenchyma were observed.

KEY WORDS: polytrauma; oxidative stress; pentoxifylline.

Отримано 05.04.19

Адреса для листування: О.О.Кулянда, Тернопільський державний медичний університет імені І. Я. Горбачевського, майдан Волі, 1, Тернопіль, 46001, Україна, e-mail: kulyanda_olol@tdmu.edu.uа. 